\title{
Bipolar Disorder and Cotard's Syndrome-A Case Report and Review
}

\author{
Gojendra Senjam,Yumnam Sana Devi, N.Heramani Singh
}

\section{Introduction}

Cotard's syndrome was first described by Dr. Jules Cotard,a French psychiatrist in $1880^{1}$. This condition is generally thought to be characterized by various degrees of delusional beliefs in which nihilistic delusion that one is dead or the world no longer exist, is the core feature ${ }^{2}$. This is a rare syndrome and till today prevalence and incidence is not known ${ }^{3}$. This syndrome is usually encountered in middle aged or older people with more commonly affecting females ${ }^{4}$.

Cotard's syndrome is seen most commonly with severe major depressive patients ${ }^{5}$,but also occur with various psycho-organic conditions like Schizophrenia ${ }^{6}$, Bipolar disorders ${ }^{7}$, depersonalisation disorder ${ }^{8}$, dementia ${ }^{9}$,temporal lobe epilepsy ${ }^{10}$, parkinson's disease ${ }^{11}$, ,rain injury ${ }^{12}$. We report a case of cotard's delusion in bipolar disorder type-II who presented with self destructive behaviour in the form of self starvation leading to sudden collapse.

\section{Case Report}

A 58 years married muslim male from a middle class family of an urban area who was undergoing treatment for Bipolar disorder type -II for the last two and half years.He was presented with sad feeling,lack of energy and lack of initiation,confining to self, sleep disturbance for about 3 weeks. His sad feelings was without obvious reason.He began to have feelings of guilt about himself and felt that he had done something wrong in his life.His sleep and appetite were reduced during this period.Gradually he started showing no interest to his daily chores and even failed to interact with his family members.

He started self talking mentioning "I had committed some sin, my life is over". He started believing that he didn't have his both hands and legs and also stomach and intestine were putrefying. Gradually he claimed that he was a death person. Subsequently he refused for food thereby leading to sudden collapse following which he was admitted in RIMS Psychiatry ward.

During first few days of admission, he refused to have food or any medications. He repeatedly said that his life was over and express regret for his past activities like a sinner.His nihilistic thought were severe enough to involve lives of his two sons and one granddaughter. He repeatedly called out their names to verify their existence.

On examination, he was not appropriately dressed, average local built and good attire. His speech was coherent and irrelevant most of the time. His mood was depressed with restricted affect. Nihilistic delusion of his body parts were absent and he was a death man, was present. His judgement and insight were absent. Systemic examination revealed no abnormality and also neurological examination were of normal range.

All routine investigations were normal range except for hypoglycaemia and electrolyte disturbance for first 3-4 days of admission. Special tests like thyroid function test, CT scan-brain didn't reveal any abnormality.

Patient was managed with injection Olanzapine $10 \mathrm{mg}$, injection lorazepam $4 \mathrm{mg}$ for first 2-3 days.As soon as he started accepting orally, we gave Olanzapine $10 \mathrm{mg}$, Lamotrigine $200 \mathrm{mg}$, lorazepam 4mg, qutiepine $2 \mathrm{mg}$ per day and responded well after 3 weeks. Mirtazapine $30 \mathrm{mg}$ was also added as his depresse feeling was not improved well.He was discharged on 28th day with following medications Mirtazapine $30 \mathrm{mg}$, qutiepine $200 \mathrm{mg}$, lamotrigine $200 \mathrm{mg}$.

In subsequent follow up for about one year,he was in full remission with lamotrigine $200 \mathrm{mg}$ and qutiepine $200 \mathrm{mg}$ while mirtazapine was gradually removed at the end of six months.

\section{Diagnosis}

Bipolar Disorder Type-II Currently in Depression with Psychotic features with Cotard's delusion

\section{Discussion}

Cotard syndrome is typically related to depression ${ }^{5}$ occurring in middle-aged or older people and more common among females ${ }^{4}$. As reported earlier ${ }^{13}$, the patient's rejection of food was life threatening and could have led to psychiatric-legal issues associated with self-starvation . Our case highlights the timely intervention 
of such patients helping in prevention of further unwanted issues. Self mutilating behaviour and suicidal attempt among these patients also reported ${ }^{14}$.

Response to treatment is variable. The most commonly recommended treatment strategy is electroconvulsive therapy $(\mathrm{ECT})^{4,15-18}$. But there are several reports of successful treatment with single or combined pharmacotherapy methods.

Table: Different drugs used in various case report

\begin{tabular}{|c|c|}
\hline Monotherapy & Combined therapy \\
\hline Olanzapine $^{14}$, aripiprazole ${ }^{8}$, fluoxetine ${ }^{19}$, duloxetine ${ }^{20}$ & 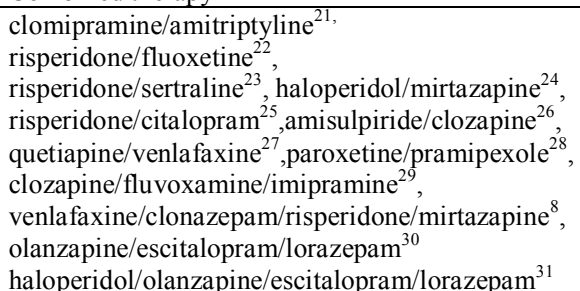 \\
\hline
\end{tabular}

But our case responded with mirtazapine/olanzapine/lamotrigine/qutiepine combination which is different available reports. So, bipolar disorder with Cotard's syndrome, antidepressant mirtazapine seems to have a role in addition to lamotrigine which has been widely used to treat simple bipolar depression.

The importance of this case is that inspite of regular medication for bipolar disorder, patient developed severe depression with nihilistic delusion with self starvation. This leads to sudden collapse creating a panic to his family members. But urgent intervention with medications as mention earlier, could return the patient's optimum functioning within one month. Even though this syndrome is rare with newer antipsychotic treatment but such case do exist which may endanger the life, like in our case. So earlier the diagnosis and treatment, better the outcome.

\section{References}

[1]. Yamada K, Katsuragi S, Fujii I. A case study of Cotard's syndrome: stages and diagnosis. Acta Psychiatr Scand. 1999; 100:396398.

[2]. Berrios G.E., Luque RCotard's delusion or syndrome?Aconceptual history.Compr Psychiatry 1995;36(3):218-223

[3]. Hans D, Michael P, Kathelijne P, and Kurt A. Cotard's Syndrome review .Mind \& Brain,J of psychi 2011; 2(1):67-72

[4]. Halfon O, Mouren-Simeoni MC, Dugas M: The Cotard syndrome in adolescents Ann Med Psychol.1985.143:876-879.

[5]. Berrios G.E., Luque R. Cotard's syndrome: analysis of 100 cases. Acta Psychiatr Scand.1995. 91(3):185-188.

[6]. Nejad AG, Kerdegari M, Reihani-Kermani H. Self-mutilation of the nose in a schizophrenic patient with Cotard syndrome. Arch Iranian Med.2007;10:540-542

[7]. Consoli A, Soultanian C, Tanhuy M, et al. Cotard's syndrome in adolescents and young adults is associated with an increased risk of bipolar disorder. Bipolar Disord. 2007;9:665_668.

[8]. Ramirez BJ et al. Cotard syndrome in Neurological and psychiatric patients .J Neuropsychiatry Clin Neurosci 22:4,2010:409-416

[9]. Conchiglia G, Delta Rocca G, Grossi D. When the body image becomes 'empty':Cotard's delusion in a demented patient. Achta neuropsychiatrica.2008; 20:283-284

[10]. Drake MEJ. Cotard's syndrome and temporal lobe epilepsy. Psychiatr J Univ Ott. 1988;13:36_39

[11]. Factor SA, Molho ES. Treating auditory hallucinations and Cotard syndrome in Parkinson disease. Clin Neuropharmacol. 2004;27:205_207

[12]. Kundlur SNC, George S, Jaimon M. An overview of the neurological correlates of Cotard syndrome. Eur J Psychiat. 2007;21:99_116.

[13]. Silva AJ,Leong GB, Weinstock R, Gonzales CL. A case of Cotard's syndrome associated with self-starvation. J Forensic Sci. 2000;45:188-190.

[14]. Peter VB.Diurnal variation in Cotard's Syndrome (copresent with Capgras delusion) following traumatic brain injury.Australian and New Zealand J of Psych 2000;34:684-687.

[15]. Stompe T, Schanda H. The Cotard syndrome in Schizophrenic disorders.Neuropsychiatr.2013 Jan

[16]. Degiovanni A., Faure M., Lévêque J.P., Gaillard P. - Cotard syndrome in young people: apropos of 2 cases. Ann Med Psychol. 1987.145:874-876.

[17]. Edelstyn NMJ, Oyebode F. A review of the phenomenology and cognitive neuropsychological origins of the Cotard delusion. Neurol Psychiatry BrainRes. 2006;13:9_14

[18]. De Berardis D, Serroni N, Campanella D, Marasco V, Moschetta FS, Di Giannantonio M. A case of Cotard's syndrome successfully treated with aripiprazole monotherapy. Prog Neuro-Psychopharmacol Biol Psychiatry.2010;37:1348.

[19]. Cohen D, Cottias C, Basquin M: Cotard's syndrome in a 15-year-old girl. Acta Psychiatr Scand 1997; 95:164-165.

[20]. Enoch MD, Trethowan WH.cotard syndrome in Uncommon psychiatric syndromes, 3rd ed.oxford: butterworth and Heinemann;1991:162-183

[21]. Hashioka S, Monji A, Sasaki M, Yoshida I, Baba K, Tashiro N. A patient with Cotard syndrome who showed an improvement in single photonemission computed tomography findings after successful treatment with antidepressants. Clin Neuropharmacol. 2002;25:276_279.

[22]. Hansen ES, Bolwig TG. Cotard syndrome: an important manifestation of melancholia. Nord J Psychiatry. 1995;36:218_223.

[23]. Debruyne H, Portzky M, Van den Eynde F, Audenaert K. Cotard's syndrome: a review. Curr Psychiatr Rep. 2009;11:197_202.

[24]. Wani ZA, Khan AW, Baba AA, Khan HA, Wani QA, Taploo R. Cotard's syndrome and delayed diagnosis in Kashmir, India. Int J Ment Health Syst.2008;2:1-4. 
[25]. Walloch JE, Klauwer C, Lanczik M, Brockington IF, Kornhuber J. Delusional denial of pregnancy as a special form of Cotard's syndrome.Psychopathology. 2007;40:61-64.

[26]. Madani Y, Sabbe BGC. Het Cotards syndroom. Differentie“le behandling volgens subclassificatie. Tijdschr Psychiatr. 2007;49:4953.

[27]. Chan JH, Chen CH, Robson D. Case report: effective treatment of Cotard's syndrome: quetiapine in combination with venlafaxine. Psychiatry Clin Neurosci. 2009;63:125-126.

[28]. Takahashi T, Nibuya M, Nomura S. Delusion of Cotard's syndrome successfully treated with a dopamine agonist. J Neuropsychiatry Clin Neurosci. 2010;27:22.

[29]. Risio DS, Rossi DG, Sarchiapone M, et al. A case of Cotard syndrome:123I-IBZM SPECT imaging of striatal D2 receptor binding. Psychiatry Res.2004;27:719-721.

[30]. Ruminjo A, Mekinulov B. A case report of Cotard's syndrome. Psychiatry(Edgmont). 2008;5(6):28-29

[31]. Gojendra SS,Heramani N,Lenin RK,Bihari Th,Khesoh N,Sidhartha D.Cotard's syndrome:A case report.JMS.2008;22(3):153-154. 